\title{
Aafrika kunstide suursugususest
}

\author{
Roger Pierre Turine
}

\begin{abstract}
Teesid
Aafrikas on tuhandeid hõime, aga mitte kõik neist ei ole loonud kujusid ega muid esemeid, mis oleksid ülendanud nende käsitööliste tehtu loovuse tippsaavutusteks. Ida- ja Lõuna-Aafrika on loominguliselt passiivsem kui Lääne- ja Kesk-Aafrika, kust pärineb põhiline osa mandri suurest ja kaunist skulptuuripärandist. Aafrika kultuskujud on alati olnud üksnes paiksete hõimude looming. Esteetika ei eksisteeri seal kunagi ilma pühaduse jõuta. Aafriklase silmis on teos ilus siis, kui see vastab tellija nõudmistele, kes tahab vahendaja abil esivanematega kontakti astuda. Skulptor - kes on tihtipeale ka külasepp - võib sõltuvalt tavadest ja olukorrast olla oma lähedastes seas vihatud, kardetud või imetletud. 2003. aastal tutvustasin Eestis Rakveres oma kogusse kuuluvat baule ja lobi kunsti. Baule esteetika oli üks esimesi, mis võlus Lääne inimesi juba 20. sajandi alguses, lobi kunst avastati aga alles hiljuti.

Eesti Rahva Muuseumis on hinnalisi mangbetu ja bembe esemeid, mis vennad Solomentsevid annetasid juba enne Teist maailmasõda. Need esemed pärinevad praeguse Kongo Demokraatliku Vabariigi aladelt.
\end{abstract}

Märksõnad: aafrika kunstid, kultusesemed, kultuskunst, kunstikollektsioonid, käsitöö, puuskulptuur

Ma ei ole ei etnoloog ega Aafrika kunsti asjatundja. Ent olgu öeldud, et kui kunstikriitiku amet mind ühel õnnelikul päeval Mustale Mandrile viis, kütkestusin otsekohe sealsetest värvidest, maitsetest ja tundmustest, millesarnaseid ei ole kogu maailmas. Järgnevatel aastatel jätkasin oma avastusretki, püüdes üha enam sulanduda sealsesse õhustikku.

Kõik sai alguse Dakari Aafrika kaasaegse kunsti biennaalist kaheksa aastat tagasi.

Tõttöelda sattusin ma Aafrika algupärastest kunstidest tõeliselt vaimustusse alles pärast teist ja kolmandat Senegali-reisi. See aeglus tundub koguni piinlikuna, kui mõelda, et rahvalik ja naivistlik kunst oli mind köitnud juba pikemat aega. Aafrika kunstid - neist peab rääkima mitmuses, sest nende eripalgelisus on niivõrd silmatorkav, - on muidugi midagi sootuks muud, isegi siis, kui neis on samuti seda liigutavalt rahvalikku, mida põhjustab andumus traditsioonidele. Niisiis läksin ma Aafrikasse mitte selleks, et saada kultuskunsti asjatundjaks pikka aega islamiusule allutatud Sene-

http://haldjas.folklore.eeltagused/nr29/turine.pdf 


\section{Roger Pierre Turine}

galis, kus kultuskunst on peaaegu olematu, vaid selleks, et tutvuda lähemalt aafriklaste nüüdisaegse loominguga, millest mulle oli räägitud kui suurte tulevikulootustega ja väga viljakast.

Esmalt jätsin kõrvale need maskid ja kujud, mida rändkaupmehed tutvustasid iidsete ja ehtsatena. Et olin võhik, umbusaldasin iseäranis nende igapäevaseid kiidukõnesid. Parema meelega sukeldusin poisikeseliku hasardiga pärast ohtraid vestlusi ja kauplemisi turistidele mõeldud nipsasjakeste vaatamisse ja ostmisse. Eks ole igaühes just nii palju seiklejaverd, kui tal parasjagu on!

Esimene biennaal ei olnud mind muide - peale selle, et õhkkond oli tõesti lummav, - sugugi veennud mustanahalise Kolmanda Maailma kunstide potentsiaalis: valik oli liiga lai, ühendades üleüldises segaduses nii meeliköitvat kui ka banaalset. Seda esimest muljet olen muidugi tagantjärele üha uuesti ja selgemini ümber hinnanud. Nüüdseks nelja Dak'Art'i biennaaliga koostööd teinuna olen saanud esmase, ilmselt liialt rutaka otsuse üle järele mõelda.

Aafrika võib varem või hiljem (ja ma loodan, et pigem varem) saada sõlmpunktiks, kust hargneb lõpuks ometi uusi impulsse oma algupära kaotavasse maailma kunstiloomingusse. Kui mõtleme sellele, et primitiivseks kunstiks nimetatule toetudes leidsid 20. sajandi kunstnikud uusi formaalseid radu, et elavdada liiga kauaks akademismi mõjusfääri jäänud väljendusviise, oleks see teatud mõttes õnnelik naasmine "stardijoonele". Kasutasin meelega väljendit "formaalseid radu", sest peale mõju, mida avaldasid põlisrahvaste kunstid suurtele modernistidele Henri Matisse'ist Pablo Picassoni, Saksa ekspressionistidest sürrealistideni, olid need kunstid kantud eelkõige põhjatust ürgtõdede allikast, esivanemate sõnumi ja väärtushinnangute suhtes tundlikust, südamepõhjas läbi elatud kultuslikust minevikust, kosmoloogilistest ja religioossetest sidemetest, mille meie, Lääne inimesed, juba ammu ("Põrgusse kõik need jumalad!") kapisügavusse oleme unustanud.

Sellest ka vältimatu tagajärg: tehisasjaks, põhjendamatuteks spekulatsioonideks taandunud tänapäevase "tsiviliseeritud" loomingu nähtavaima osa väljakannatamatu tühjus, mis teeb iga päevaga üha nukramaks. Ta tõukab kaelast saadik loomingulise aktuaalsusega seotud kunstikriitikut välja kaevama üha rohkem traditsioonilise loome kujutavaid ja kultuslikke tõdesid, neid, mis on kantud austusest nii loomisakti enda kui ka usu vastu teda valitsevatesse jumalustesse. 
Et minu kirjutis on pigem esseistlik ja tutvustav, soovitan neile, kes tahavad allpool kirjeldatavate rahvastekunstiga lähemat tutvust teha, mõningaid raamatuid, mis mulle endale on ühes või teises mõttes juhatust andnud (näit Bacquart 1998; Cornet 1972; Kerchache \& Stéphan \& Paudrat 1998 ; Leuzinger 1962 (1961); Phillips 1999; Rubin 1991 (1984) ; Salmon et al. 1976; Scanzi 1993; Stepan 2001; Vogel 1999 (1997); Willett 1990 (1971, 1993, 1994)).

Peaksime olema tähelepanelikud kahes asjas. Tugeva omandiinstinkti tõttu, muretsedes eelkõige enda heaolu ja oma rikkuste tehnilise arengu pärast, oleme me hävitanud Aafrika terviklikkuse ja tema väärtused. Kolonisatsioon tegi ühe sajandi jooksul olematuks tuhandeaastase kultuuri. Õnneks - ja siin ei mängi meie enam mingit rolli - on Aafrikal ja aafriklastel nii tugev identiteet, et neile jääb, loodame, et ka tulevikus, kõigest hoolimata oma muutumatu osa tõelusest.

Viimane on tänapäeval elujõuline eelkõige paikades, mis asuvad eemal emantsipeerunud linnadest ja keskustest, kus ülitugevad Lääne mõjud on vorminud aafriklasegi oma mudeli järgi. Traditsioonilised religioonid, ei sugugi halvemad ega paremad kui meie oma, mida miskipärast peetakse tähtsamaks ja väärikamaks, on linnapiirkonnad tõepoolest maha jätnud. Kunst on nendega kaasa läinud, eemaldudes põlisküladesse, kaugele inimmassidest ja suveniirikaupmeeste poolt laastatud paikadest, kus juba aastakümneid on tegutsenud tõelised koopiatöökojad, mis varustavad kogu maailma poode võltsitud baule, bakuba või fangi kunstiga. Enamasti on see õnneks keskpärase kvaliteediga.

Mõned metsikumad hõimud, need, kes oma juba leebunud või liiga agressiivsetele vallutajatele kõige hiljem alla andsid, - kogu 20. sajandi oleme olnud tunnistajateks "kohalike iidolite hävitamisele" - pidasid vastu, säilitasid oma kultuuri ka sajandite möödudes, kuigi lakkamatud hõimudevahelised sõjad olid sundinud neid liikuma aina uutele eluks hädavajalikele maadele.

Okupandid-kolonisaatorid - nad kõik võib panna ühte patta, olenemata sellest, kas nad olid belglased, prantslased, inglased, hispaanlased, sakslased, hollandlased, portugallased või itaallased käitusid näruselt, tõmmates piire seni selgelt piiritlemata maade 


\section{Roger Pierre Turine}

vahele. Nii said alguse kurioossed piiritõmbamised, mis põhjustasid vahel sedagi, et mõni rahvas leidis end mitmele territooriumile paisatuna. Näiteks jaotati lobid Burkina Faso, Côte d'Ivoire'i (Elevandiluuranniku) ja Ghana vahel, tšokvesid leiame nii Kongo Demokraatlikust Vabariigist kui ka Angolast, fange Gabonist, Ekvatoriaal-Guineast ja Kamerunist. Need on vaid kolm näidet kümnete sarnaste seas.

Kas, ja kui, siis kes muretses neid eraldusjooni vedades kõnealuste hõimude heaolu ja identiteedi pärast!

Kuigi nii mõnedki vallutajate vastu vaenulikuks jäänud hõimudest jätkavad oma traditsioonilist eluviisi tänapäevalgi, viib kiire uuenduslikkus ja üleilmastumine aina rohkem noori eemale kohalike elutingimustega kahtlemata paremini sobivaist esivanemate kommetest ja tavadest.

\section{Esteetilised ja kultuslikud eripärad: bauled ja lobid}

Juba kuus aastat olen keskendunud võimaluste piires põhjalikule uurimistööle Aafrika pärismaalaste esteetika omapäradest. Pean tõele au andes tunnistama, et see on eelkõige visuaalne uurimus, sest nii on lihtsam: loomuliku initsiatsiooni puudumisel on enneolematult keeruline siseneda mingi rahva traditsioonilistesse uskumustesse ja maagilistesse toimingutesse isegi siis kui need uskumused - vastupidiselt levinud arvamusele - ei ole oma olemuselt monoteistlikest religioonidest kuigi kauged.

Tähtis osa nende uskumuste edasiandmisel oli suulisel pärimusel, sest Aafrika oli alles hiljaaegu kirjaoskamatu ja kombed arenesid siin aegamööda, suuliselt vahendatud tarkusi järgides. Kuigi masside moderniseerumisest tingitud ravimatud laastamistööd on murendanud vanade alalhoidlike põhimõtete järjekindlust, mis oli elujõuline veel 30 aastat tagasi, on Aafrika algupäraste religioonide keerulisus ja variatiivsus ka tänapäeval niivõrd suur, et eurooplasel on neis äärmiselt raske orienteeruda ilma, et ta kaotaks end väljapääsuta labürintide rägastikku. Selline saatus ootab eriti pühendamatut, kellel on hulljulgust tahta haarata kõike korraga: nii kosmogooniaid ja filosoofiaid kui ka nende metafüüsilisi rakendusi. Sest mustanahalised pole sugugi olnud barbarid ega metslased - 
vastupidi, nad on ilmutanud vägagi kõrgetasemelisi mõtteviise. Piisab süvenemisest dogoni kosmogooniasse mõistmaks, et nende tarkus, olles ühtaegu keeruline ja lõpmatu, kindel ja püha, on meile enam kui raskesti hoomatav.

Tuleb teada sedagi, et Aafrikas on tuhandeid hõime, aga mitte kõik neist ei ole loonud kujusid ega muid esemeid, mis oleksid ülendanud nende käsitööliste tehtu loovuse tippsaavutusteks. Kuigi masaide, makondade, sukumade, sulude ja tsongade loomingut ei saa kaugeltki alahinnata, on Ida- ja Lõuna-Aafrika loominguliselt passiivsem kui Lääne- ja Kesk-Aafrika, kust pärineb põhiline osa mandri suurest ja kaunist skulptuuripärandist. Samuti peab teadma, et Aafrika kultuskujud olid ja jäävad paiksete hõimude loominguks. Rändhõimud, näiteks pulaarid ja tuareegid, kes ei saanud raskesti kantavaid esemeid oma rännakutele kaasa võtta, on loonud pigem ehteid või otseselt praktilise väärtusega esemeid, nagu seda on graveeritud või põletatud mustritega kõrvitsakoortest nõud.

Esteetika iseenesest aafriklast ei puuduta, see ei eksisteeri kunagi üksi, ilma pühaduse jõuta. Viimane, vastupidi, avaldub iseeneslikult ja võimsalt tingimusel, et oleksime avatud teise isiku ohverdusideaalidele. Neis aastate vältel pidevalt lihvitud, luitunud Aafrika kujudes on peidus valu, ohverdusi ja eneseohverdusi, usku, lootusi ja ootusi, lubadusi ja annetusi, imetlust ja austust. Nad on sageli üle valatud ja niisutatud ainetega, mida annetusena maajõududele nõudis nendega pidevas ühenduses olev ennustaja-külatark. Ohvriandidega heatahtlikuks muudetud maajõud olid omakorda vahendajaks külatarga ja jumaluste vahel.

Aafriklase silmis on teos ilus siis, kui see vastab tellija nõudmistele, kes tahab vahendaja abil esivanematega kontakti astuda. Mis muidugi - ja rohked õnnestumised on selle tõestuseks - ei sega kuju tegijal andmast endast parimat, lihvides peensusteni välja detailid või rõhutades vorme ja jõujooni, sellega oma tööd eripärasemaks muutes. Samas ei unustata iial hõimuskulptuurile esitatud erinõudeid ja omadusi, mis peavad vastama rituaalsetele vajadustele.

Skulptor - kes on ühtlasi tihtipeale ka külasepp - võib sõltuvalt tavadest ja olukorrast olla oma lähedaste poolt kas vihatud, karde- 


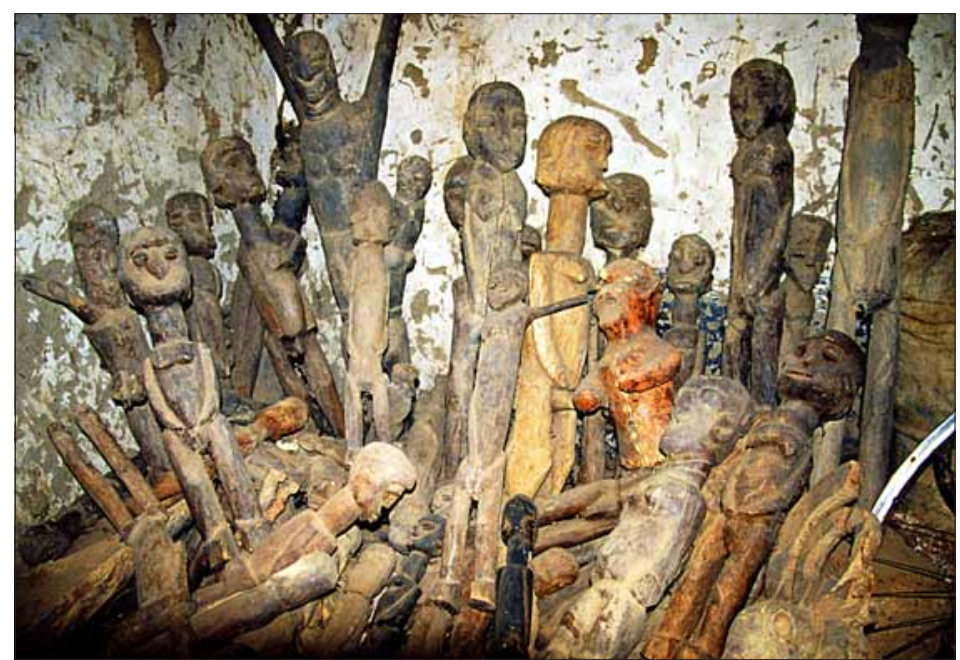

Foto 1. Lobi rituaalsed puuskulptuurid Lassie külas. Ghana 2003. Kadri Viirese foto.

tud või imetletud. Mõnikord - nagu näiteks bakubade juures - on ta kuningat teeniva isikuna ülendatud üliku seisusesse.

*

Mul läks üüratult kaua aega, enne kui ostsin esimese Aafrika skulptuuri. Õigupoolest tuli ta meie juurde ise, mu eestlannast abikaasa ja minu juurde, enne meie esimest Senegali-reisi, kui jalutasime armunud abielupaarina Brüsseli vanakraamiturul. Oma kolonistimütsi, õieli rindade ja suurtest sisselõigetest lõhestatud näoga suutis see Nigeeriast pärit ibo skulptuur veenda meid end ostma. Oli ta siis ehtne või mitte, sobis ta siiski hästi meie sooviga teha midagi ootamatut. Et me end kujuga samas toas kuigi mugavalt ei tundunud, panime ta külalistetuppa, kus ta ajas hiljem hirmu nahka ühele noorele Eesti kunstnikule, kes tunnistas, et ei suutnud selle kõrval silmatäitki magada. Kolonistimütsiga Ibo leidis oma koha ja pani end veenvalt maksma alles aastaid hiljem - siis, kui meil tekkis võimalus ta teiste aafrika skulptuuride sekka paigutada.

Tegelikuks sütitajaks mind üha enam haaravale kirele musta mandri kunsti vastu sai aga kohtumine pulaari karjuse Ibrahimiga. 
Roger Pierre Turine

Olin täiesti juhuslikult sisenenud Antverpeni maailmakultuuri keskuse tagasihoidlikku poekesse, kus kõnealune mees töötas LääneAafrika tsivilisatsioonide eksperdina, kui mu silma puutus üks imelike kommetega puust paarike. Kuju oli kasutatud mingil riituselsellest andsid tunnistust teda kattev paatina ja liivas seismisest päevi näinud sokkel.

Ibrahim seletas mulle, et tegemist on lobi paariga, kes, olles püstiselt vahekorras, väljendavat viljakustahet. Sain kuju endale. Ent sellega asi ei lõppenud. Tulid ka järgmised ostud, esmalt lobi skulptuurid, hiljem palju muudki.

Nii tekkis meil võimalus eksponeerida 2003. aasta suvel Rakveres Teet Veispaki ettepanekul näitust, mis oli keskendunud kahe suhteliselt lähestikku elava hõimu - lobi ja baule - kunstile. Olles küll naabrid, väljendavad need etnilised rühmad oma kunstilisi arusaamu üsnagi vastandlikult. Just see tunduski huvitav: jagada eesti näitusepublikuga (enamikule oli see nende esimene kohtumine Aafrika pärimuskunstiga) tõdemust sellest, mil määral võivad Aafrika kunstid üksteisest erineda isegi siis, kui nende ühine lähtepunkt on sama: ohverdused jumalatele, kellele tahetakse olla meele järgi selleks, et tagada oma lastele häid viljasaake ja õnnelikke päevi.

Kui baule esteetika oli üks esimesi, mis võlus Lääne inimesi juba 20. sajandi algusest peale, siis lobi omal kulus palju rohkem aega, enne kui ta suutis neid oma ahvatlevuses veenda. Tänu sellele, et lobi kunsti tegelik avastamine on üsna hiljutine nähtus, on asjaarmastajal võimalik leida veel tänapäevalgi skulptuure ja esemeid, mis vastavad tema ootustele algupärast.

Kui tahta üldistada, siis võib öelda: baulel on kalduvus lihvida oma tööd sedavõrd, et viimane võib päädida ilus, mis lahjendab tema ürgset jõudu. See ei käi muidugi baule suurteoste kohta, mis on äärmiselt peene faktuuriga, täis graatsiat ja kujundlikku rikkust nii peahoiu, soengute, nägude, käte-jalgade, aga eriti keha nõtkuse kujutamisel.

Tüüpilisemad baule kujud on:

- "Teispoolsuse abikaasad" - Blolo Bla ja Blolo Bian - vastavalt naisvõi meessoost kodukujud, mille vahendusel astutakse kontakti omakorda maajumalustega suhtlevate surnud lähedastega; 


\section{Roger Pierre Turine}

- asie usu'd, mis kehastavad metsadesse eemaldunud jõude ja hingi, kellele tuleb tuua ohvreid selleks, et mitte nende viha alla sattuda;

- inimkujulised ahvid, kelle välimus on eelnevatest rohmakam ja kellele annetasid enamasti põllu- ja metsatöödega seotud riitusi pühitsevad talupojad.

Kui metsavaimudele pühendatud asie usu't kujutati meeleldi kauni ja inimnäolisena selleks, et inetu vaim soostuks kujusse elama asuma, siis talupoegade seas austatud metsa-ja põllujumalused olid looma-, sageli ahvikujulised. Neid hoiti väljaspool küla asuvas hütis, naiste silma alt eemal. Teatud kuufaaside ajal ning külviaegadel pani selleks määratud vahendaja looma pea peal või kätel asetsevasse anumasse toiduande, lootes olla jumalusele meelepärane, kaitsta küla heaolu ja avitada ohus olevaid põllukultuure.

Minu esimene kontakt lobi rahvaga leidis aset tuhandete kilomeetrite kaugusel Gaouast, lobide pealinnast, kus elab mitmeid etnilisi rühmi, keda peetakse põhimõtteliselt vähem või rohkem lobidega suguluses olevaks. Piisas ühest "Lobi lollusest" (nii nimetatakse suguühet kujutavat viljakusskulptuuri, mille ostsin Antverpenist), et paisata mind Aafrika kunstide lumma järgivatele radadele.

See lumm on mõistagi ohtlik. Ja moraalselt laastav, kui mõelda sellele, et niisuguste vaimu ja tähenduslikkust pilgeni täis esemete ihaldamine toob mõnes mõttes kaasa ühelt kultuurilt tema kõige algupärasema osa jõuga äravõtmise. Muide, ka algajast eksootikahimulisele kollektsionäärile, kes liiga ruttu tahab osta kunsti, mille mõistmine talle üle jõu käib ja mis kaotab suure osa oma kosmilisest ja sakraalsest jõust niipea, kui jõuab muuseumi või erakogu vitriini, on see omandamise-illusioon moraalselt laostav. Tunnistan, et olen teinud vigu ja kogenud mõlemat valu. Ent ma ei kahetse seda lumma, sest ta avas mulle hoopis teise vaatepunkti väga tundlikele reaalsustele, mille väärtus on mõotmatult suur ka siis, kui oleme suutelised hoomama neist vaid väikest osa.

Sestpeale olen püüdnud minna sügavuti Aafrika nelja ilmakaare kunsti etniliste omapärade mõistmisel. Kuigi ma pole kaugeltki asjatundja, kes suudab eksimatult kindlaks määrata kuju, maski või muu eseme päritolu ja autentsuse, on mul nüüd siiski sedavõrd teritatud silm, et võin öelda, kas tegu on umbrohuga või mitte. 
Mis puutub nn esmaste kunstide autentsuse määramisse, siis kehtib siin nagu mujalgi suhtelisuse kainestav reegel. Ta õpetab, et aegade ja maitsetega koos muutuvad ka hinnangukriteeriumid.

Ainsad kunstiteosed, mille autentsuses võib kindel olla, on need, mis toodi Läände hiljemalt 20. sajandi esimestel kümnenditel. Need on pika aja vältel kaardistatud esemed, mille ajaloo on meile pärandatud kohapeal reisinud inimesed, kelle sõnades pole söandanud kahelda ükski neile järgnenud asjaarmastajate põlvkond.

Mis puutub esemete oletatavasse vanusesse, siis jõudu sellele, kes suudab selle kindlaks määrata! Nende asjade välimuse on kujundanud nii säilitustingimused, kasutatud puu kvaliteet kui ka piirkondlikud ilmastikuerinevused. Rääkimata sellest, et mõnede silmis seisneb Aafrika kunstiteose väärtus tema rituaalses käibes, millest annavad tunnistust paatina ja manipulatsioonijäljed, vanus ei loe siin suurt midagi. Teistele - ja sellele rõhub eriti Lääne mõtteviis - määrab eseme väärtuse tema esteetiline kvaliteet.

Ülalöeldut silmas pidades peaksid eseme riituslik tähendus ja esteetiline ilu käima käsikäes, muidugi pole viimane kunagi päris vaba subjektiivsusest.

*

Siinkohal tundub mulle vajalikuna öelda, et Aafrika kunst on eelkõige suhtlemise kunst. Selles peitub tema esmane tõde, aga ka selle tõe tunnetamise haprus meile: on ääretult kohatu uskuda, nagu võiksime olla suutelised suhtlema elavate jõududega, saama osa meile nii võõrast pühadusest ja sellega käsikäes käivatest maagilistest toimingutest. Tunnistagem asjakohase tagasihoidlikkusega, et me ei suuda ealeski tajuda aafrika kunsti nii, nagu seda teeb aafriklane. Me seisame keset tühjust seal, kus tema suhtestub esemetega, mis on truudussidemeis teda valitsevate jõududega. Siit ka meie lähenemise vältimatu marginaalsus, mis - ja olgem sellega rahul - ei pisenda kuigivõrd väge, mida arvame end tundvat siiralt imetleva vaatluse hetkel.

Aafrika kunst kõneleb teistele kultuuridele avatud eurooplasele oma imelisest ainulaadsusest. Temasse kätketud emotsioonide ja usutalituste laeng on sedavõrd tugev, et selle kiirgus ei jäta tundetuks ka meid, keda ta vaid riivamisi puudutab. Sellest ka tema võlu ja õppetund, millest meilegi on antud osa saada tingimusel, et süveneme sellesse ja armastame seda nagu teadvuse väljundit, mis 


\section{Roger Pierre Turine}

kõnetab meid oma sügavuse ja võimega tõlkida kunstikeelde vajadusi, ihasid ja väljakutseid, mis meid - tihti endalegi ootamatult loodusseaduste järgi ühendavad.

Vaatan tihti kujusid ja maske, mis meid meie kodus ümbritsevad. Mõnikord olen sunnitud tunnistama, et nad võtavad liialt võimust. Enamasti aga ei tunneta ma seda niiviisi, sest igaüks neist tuletab mulle meelde enneolematuid vaimseid ja visuaalseid rikkusi. Aafrika skulptuuridele peab lähenema tihti, elama niivõrd kui võimalik nendega koos, neid puudutama, laskma nende valgusel, ebatavalise faktuuri võludel, dramaatilisusel või imeliselt leidlikul vormil endasse imbuda. Neid peab nägema armastusega, avastama neis peeni detaile, aga ka rõõme ja palveid, mida on loetud nende valmistamisel. Aafrika kujude algupäras väljendub nende seos päritoluga, seos, mille mõjujõu nad on suutnud säilitada ka siis, kui nad on oma biotoobist kaugel ja sellest lahutatud. Seda jõudu tunnetanuna ei suuda ma tema lähedusest enam loobuda. Sest temas on lunastust ja osasaamist kõigest hoolimata.

\section{Ilu ja vägi}

Rakveres esitlesime baule skulptuuridega kõrvuti lobide loomingu olulist sarja. Mulle tundus sobivana ühendada baule skulptorite erakordselt osav ja esteetiliselt nauditav väljendusviis skulptori staatust mitte tundvate lobide omaga, kus kuju võib valmistada igaüks, kel vajadus esivanematega suhelda.

Samuti tundus mulle huvitav esitleda niisuguse hõimu kunsti, kes oli suutnud võõrastele mõjudele sedavõrd suurt vastupanu osutada, et säilitas 21. sajandi alguseni oma eripära ja täiesti omanäolise elustiili.

Lobide meieni suhteliselt hiljaaegu jõudnud looming sai esmalt asjatundjate tõrjuva hoiaku osaliseks, sest viimased olid harjunud Kesk-Aafrika kauni paatina ja baulede, jaurede, agnide, danide ning Elevandiluuranniku hõimude delikaatsema eneseväljendusega. Ja ometi, milline jõud peitus neis tahumata puust tehtud olendites, milline dünaamilisus ja lausa lõikav väljendusrikkus!

Nad on rahutud ja tapavad oma nooltega! ${ }^{1}$ - nii hoiatati eurooplasest seiklejat, kes suundus lobisid avastama veerand sajandit tagasi. Vaatamata sellele, et tänapäeval niisugune hoiatus enam ei 
kehti, on ammustest aegadest omaette hoidvad, külalislahkuseta ja sõjakad, koguni vennatappudega kuulsust kogunud lobid säilitanud oma mässajaliku meele tänaseni. Nad ei lase endale liiga teha, ja peavad jahti - nagu ennevanasti - vibu ja nooltega. Loomult individualistid, ei tunne nad tsentraliseeritud poliitilist struktuuri ja elavad endiselt suveräänsete peredena.

Üks Prantsuse ametnik märkis aastal 1931:

Lobi küla kujutab endast kindlustatud elamute laialipillatud kogumit, kus pered elavad üksteisest üsna kaugel (Haumant 1998: 5).

See märkus, nagu tema põhjuski, kehtivad ka tänapäeval: lobi elamute laialipillutatus aitab nende elanikel vältida kiirelt tekkivaid tülisid naabritega. Lisaks sellele on küla niisugune ülesehitus strateegiliselt nutikas: võimalikul vaenlasel on peaaegu võimatu seda korraga ümber piirata.

Lobid ohverdavad esivanematele ja selle tänini elava riituse tarbeks valmistavad nad kujukesi ja amulette, mis on tähelepanuväärselt napid ja silmatorkavalt suure sisemise jõuga. Igal lobi perel on oma kultusese, mille tarvis ehitatakse pere elamisse eraldi ruum. Tema ülesanne on kaitsta perekonda kõige eest, mis on ühiskonnas halba: nõidade, haiguste, halva õnne eest. Olles animistid nagu paljud nende naabridki, on lobid loonud hulga kultusesemeid, mis peaksid neile kindlustama vaimude heatahtlikkuse või vahel ka vastupidi: kaitsma inimesi vaimude viha eest. Lobide maalt leiame kultuskujusid, mis aitavad karistada vargaid ja abielurikkujaid, kujusid, mis kindlustavad abikaasa truuduse ja viljakuse, kaitsevad haiguste või nõidade eest, tagavad rikkuse ja heaolu...

Pikka aega avalikkusele tundmatud, ei ole lobi skulptuurid loodud eesmärgiga lummata vaatajat oma kunstilise teostusega. Neil ei ole peenelt punutud, maitsekalt viimistletud ja kaunilóikelisi soenguid. Ei ole ka kaskaadina mõjuvaid detailitäpseid sisselõikeid kehal. See, mis lobi kujude juures kõigepealt silma torkab, on nende hämmastav selgus, hierarhiline otsevaatelisus, piirdumine olulisimaga. Nad on tehtud tugevat vastupanu osutavale puule mõeldes, neil on sageli rippus käed ja rõhutatult väljendusrikas pea.

Lobi skulptuuride puhul on tegemist palju enamaga kui seda on lihtsalt voolitud kuju: need verega kastetud ja ohvriandidega kae- 
Roger Pierre Turine

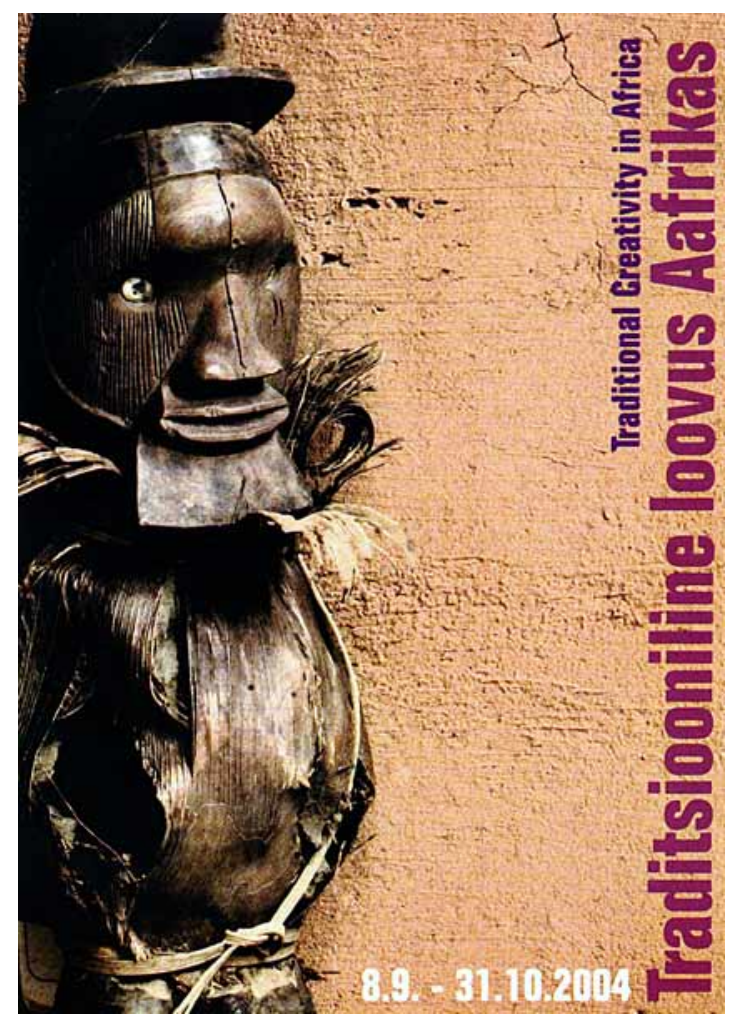

Foto 2. Tartus Eesti Rahva Muuseumis 2004. aasta sügisel eksponeeritud näituse "Traditsiooniline loovus Aafrikas" plakat.

tud, spetsiaalselt nende tarbeks ehitatud ruumi paigutatud esemed täidavad Thila funktsiooni.

Et selle sõna tähendusest paremini aru saada, pean tagasi tulema Aafrika pärismaalastele iseloomuliku kunsti ja religiooni lahutamatute seoste juurde.

Iga lobi küla on allutatud kindlale käitumismudelile, mille ta saab Thililt. Viimast esindab dithildaari ehk maavanema järelevalve all olev püha altar.

Thil - see on suuliselt vahendatav keeldude ja kohustuste loend selleks, et kindlustada külaelanike harmooniline kooselu ja tagada inimeste ühtehoidmine ning üksteise abistamine ohuhetkil, ma- 
janduslikult rasketel aegadel või sõja korral. Kui seda mudelit täpselt järgida, kaitseb see kogukonda ja tagab talle oodatud heaolu.

Seejuures tasub teada, et lobi usub ühte jumalasse kui universumi loojasse. Selle universumi sisemuses aga tiirlevad kõigepealt üleloomulikud ja nähtamatud olendid, poolinimesed-pooljumalused - Thilad. Neile järgneb surnute rahvas - kontuossi -, kes on eemaldunud võsasse või taganenud veevoogude sügavusse ja kellest ei teata õieti, mida oodata: kord teevad nad head, kord halba. Ja alles rongkäigu lõpus kohtame elavaid - inimeste kogukonda.

Tangbale - loojale-jumalale, ühele ja jagamatule, kes eemaldus inimkonnast pärispatule järgnenud päeval, pole pühendatud ühtegi kultust. Samuti ei tea me midagi kontuossidele määratud ohvriandidest. Küll aga annetati vähemalt kord aastas Thiladele selleks, et Maad kehastav ja viljastatud Tangba abikaasa kindlustaks inimestele hea viljasaagi.

Kokkuvõttes on on Thilad üsnagi vormitud ja piiritlemata olendid, vastupidiselt bateba'dele, kes annavad kuju ja vormi nii lobide uskumustele kui ka nende kunstile.

Lobide suhe jumalustesse ja eriti thiladesse toimib bateba'de vahendusel ja näpunäidete alusel, mida nad saavad selgeltnägijailt-külatarkadelt (Gottschalk 1999).

Niisiis ongi batebad need kujud, mida meisterdavad küla käsitöölised, kuid ka ükskõik milline lobi, kes vajab jumala toetust. Bateba'sid käsitletakse kui elusolendeid, kes elustuvad hetkest, mil nad asetatakse perekonnaaltarile või allutatakse thilale, ja kes on võimelised nägema, suhtlema ja liikuma, et kaitsta ja aidata inimesi kõikvõimalikel viisidel ja kõikvõimalikes eluvaldkondades.

Nõnda kulgebki lobide elu selgeltnägijate juures veedetud nõustamisseansside ja ennustamisriituste rütmis. Ja just selgeltnägijad või ennustajad on need, kes lobile ütlevad, millist batebat tollel on vaja, et suuta võita thila soosingut.

Batebasid on erinevates suurustes ja erinevat tüüpi: vihase näoga bateba'd, kui neil tuleb vastu seista nõidadele; istuvas asendis batebad, kui nad on kaitsvad majahoidjad; välja sirutatud või üles tõstetud kätega batebad, kui nende ülesanne on ähvardada või turvata; ühe keha ja mitme peaga batebad, kui nad peavad sisendama hirmu; taeva poole sirutatud kätega batebad, kui nad peavad paluma vihma; ühtepositsioonis batebad, kui neilt oodatakse viljakuse õnne... 


\section{Roger Pierre Turine}

Lisaks inimnäo ja -kehaga batebadele on olemas ka loomakujulised batebad.

Lobi käsitöölised valmistavad ka tantsu- või võitluskeppe, jahivilesid ja muusikariistu, kolme või nelja jalaga taburette, mis on mõnikord kaunistatud peakujuliste detailidega. Nad voolivad puust, harvemini elevandiluust ja valavad pronksi, valmistades niiviisi ehteid ja amulette.

\section{Kuba, luba, songje, bembe, mangbetu...}

Tartus asuval Eesti Rahva Muuseumil on õnn olla mitme mangbetu ja bembe kultuurist pärineva eseme omanik. Need enne Teist maailmasõda vendade Solomentsevide poolt ülikoolilinna muuseumile annetatud esemed on valmistatud endises Zairis (praeguses Kongo Demokraatlikus Vabariigis), kunagises Belgia koloonias, mille territoorium on kaheksakümmend korda Belgiast suurem ja mille traditsioonilise loovuse maine on erakordselt kõrge.

Kongo rikka loomingulise pärandiga rahvaste - lubade, kubade, tekede, songjede, bembede, legade, jakade, sukude (ja seda nimekirja võiks täiendada lõpmatult) - loodu hämmastab oma stilistilise mitmekesisusega. Peatugem neist mõnel veidi pikemalt.

Bashi-Bushongo ehk kuba (nimi, mille nad said teiselt kuninglikult hõimult - lubadelt) kunst on tüüpiliselt õukondlik kunst, kus kuningas ehk nyimi kehastab ühiskondlike, poliitiliste ja religioossete jõudude võimsust ja allikat. Vastavalt suulisele pärandile, on Bushongodel ehk kubadel olnud üle 125 kuninga, keda nad võivad nimepidi nimetada. Nende kuningate äärmiselt haruldased, aga kuulsad skulptuurid, mille näiteid leiame Tervureni, Kinshasa ja Briti Muuseumi kogudest, kujutavad nyimit ristatud jalgadel istuvana, peaga, mille suurus moodustab kolmandiku kehast, ja igale valitsejale ainuomase atribuutikaga, mis võimaldab nyimi-kujude eksimatut identifitseerimist.

Sageli muljetavaldavad kuba maskid on väga erilised, mõnikord kiivrikujulised, klaaspärlitest, teokarpidest, nahast või riidest kaunistustega. Nad tuuakse välja tavaliselt matustel ja muudel initsiatsiooni- ehk siirderiitustel.

Kubadele iseloomuliku kuningliku kunstiga (skulptorid kuulusid ja kuuluvad tõenäoliselt endiselt kuninglikku õukonda) kõrvuti 
tuleb mainida nende kõrgetasemelist dekoratiivkunsti, kus enami$\mathrm{ku}$ argieseesemete rikkalik ornamentika on tegelikult laenatud kubade allhõimu šoovade viljeldavast, nn Kasai sametina tuntud ja hinnatud tekstiilikunstist. Kuba skulptuurid, trummid, ennustamisel kasutatavad loomakujukesed, meigikarbid, piibud, sauad, viske- või võimuatribuutidena kasutatavad noad, kaunilt töödeldud laiad vööd on kõik tähelepanuväärse teostusega.

Lubad, keda on raske kellegi teisega võrrelda, elavad maalapil, mis hõlmab suurt osa Katangast (Shabast) ja osa Kasaist. Nad jagunevad kolmeks rühmaks: luba-katangad, luba-hembad ja lubakasaid. Luba rahvas on väga aktiivne ja töökas ning kohtleb oma käsitöölisi suure austusega. Nad on meile pärandanud suurepäraseid esivanemate kujusid, maagilisi figuure, millest õhkub vaoshoitust ja väärikust, vaimustavaid karüatiididega istmeid, tundlikult ja peenelt teostatud olmeesemeid. Luba hämmastavalt kauni esteetika põhijoonteks on vormikas ümarus ja paindlik modellikäsitlus, lisaksin ka, et äärmine sensuaalsus. Kuna naisel on luba kunstis väga oluline koht, siis ilmselt see seletabki äsjaöeldut.

Songjed elavad luba-hembadest põhjas ja luba-kasaidest idas. Ka neil on rikas, enamasti kultusesemeist koosnev skulptuurilooming, mida iseloomustab kubistlik vorm ja vähene tõetruudus, kuid seeeest suur väljendusrikkus. Songje mehekujud on sageli varustatud maagiliste ainetega (need kujule väge andvad ained võivad olla erinevat päritolu - küüned, suled, ussinahk jms), mis peidetakse kõhtu uuristatud lohku või lagipähe voolitud väikese sarve sisse. Nende tihti suuremõõtmeliste kujude ülesandeks on suurendada naiste elujõudu ja tõsta nende viljakust, samas kaitsevad nad küla kurja silma, haiguste ja ebaõnne eest. Noore kuu ajal toovad naised nad onnidest välja, tantsivad nendega ja ohverdavad neile.

Tšokved elavad enamalt jaolt Angolas, kunagises Portugali koloonias, kuid väike osa sellest olulisest hõimust elab ka Kongo DVs. Tšokvede algupärast kunsti hinnatakse üheks silmapaistvamaks kogu Aafrikas. Olles ühtaegu nii õukonna- kui ka lihtrahva kunst, ei keela ta endale teatud dünaamilist baroksust. Naabritelt kubadelt ja luluvadelt päritud dekoratiivsus, mida täiendab lubadelt laena- 


\section{Roger Pierre Turine}

tud pehmejooneline monumentaalsus, lisavad tšokve kunstile mõjujõudu.

Teked, bembed ja bvembed elavad kahel pool piiri Kongo Vabariigi (endise nimega Brazzaville'i Kongo) ja Kongo DV ehk endise Zairi vahel. Eesti Rahva Muuseumis on mõned teke kujud, aga eriti kaunid on muuseumi kollektsiooni kuuluvad bembe figuurid. Need on suhteliselt väikesemõõtmelised, peente sisselõigetega kehal ja kujutavad esivanemaid.

Tekedel omakorda on kujusid ja kujukesi, mida kasutatakse ennekõike talismanina igasuguste haiguste vastu, jahiõnne edendamiseks, viljakuse suurendamiseks jne. Maagilised ained, mida teked neile lisavad, peidetakse kuju katva paksu savi- või tekstiilikihi alla. Tavaliselt on teke kujud varustatud habemega ja nende näod on siiruviirulised.

Bakongod ehk kongod on Kongo DV üks suurimaid hõime. Nad jagunevad omakorda mitte vähemtähtsateks allhõimudeks: jombedeks, vilideks, sundideks, vojodeks jne. Enamasti kujutavad kongode puust voolitud kujud esivanemaid, mõnikord ka jahimehi ja emadust. Kiviskulptuurid, mida kutsutakse ntandi'deks, on kasutusel surnuaedades hauakividena.

Kongo skulptuur on vaieldamatult Aafrika üks realistlikumaid. Sarnaselt bembedele kaunistavad ka nemad oma kujusid hõimutunnuseid kandvate sisselõigetega. Aga mitte ainult: samasuguseid sisselõikeid lasid endale teha ka kongo naised eesmärgiga end kaunimaks muuta.

Kongod on kuulsad oma nkisi'de ehk naeltega kaetud kultusesemete, fetish'ite ${ }^{2}$ poolest. (Sõna fetish, eesti keeles fetiš tuleb muide portugalikeelsest sõnast feitiço, viimane omakorda ladinakeelsest sõnast factitius, tähendades 'inimkäega valmistatut'.) Maagilised ained, mis on peidetud kujutatava olendi - olgu selleks olendiks inimene või loom - pähe või kõhtu, täidavad kahekordset funktsiooni: nad toimivad ühtaegu nii ähvardusena, saates välja needust ja halba jõudu, kui ka kaitsjana oma omaniku suhtes.

Kongodel on rohkesti enam või vähem püha staatusega olmeesemeid: skeptreid, kärbsepiitsu, trumme, piipe jne.

Jakad, sukud, nkanud, holod ja hunganad elavad Kwangos ja Kwilus. 
Põllu- ja jahimeestest jakadel on esivanemate kujukesi, kultusesemeid ja maske, mida kasutatakse eelkõige ümberlõikamisriitustel. Neil maskidel on muu hulgas omalaadne superstruktuur: inim- ja loomakujudega kaunistatud pealeehitis. Jaka inimest kujutavatele skulptuuridele on iseloomulik ülespidine, mõnikord isegi karikatuurne nina ja suurte rõngastega ümbritsetud silmad.

Suku ja holo kunstil on palju ühisjooni jakade loominguga.

Pended elavad Kwilu piirkonnast idas ja Kasaist läänes. Loango jõgi jagab pendede asuala kaheks. Skulptuur on selle hõimu juures haruldane nähtus, seevastu kiududest punutud või puust maskidel on pendede ühiskonnas täita oluline osa. Neid maske on kolme tüüpi: mingangid, mbujad ja giphogod. Esimesi kasutatakse eelkõige esivanemate kultuse talitustel ja pealiku trooniõnnistamise tseremooniatel, teisi noorukite initsiatsiooniga seonduvalt, kolmandad on pealikute maskid.

Samu maske esineb ka vähendatud kujul; neid puust või elevandiluust valmistatud väikemaske nimetatakse ikhokodeks ja kantakse kaelas.

Legad ja bembed (neid ei tohi segi ajada teiste, juba mainitud bembedega!) elavad Kongo DV põhjaosas Maniemas. Nende valmistatud esemed, vastupidiselt teistele hõimudele, ei teeni kultuseesmärke, vaid on bwami usulahu eraldusmärgid. Viimane ei kujuta endast tõelist salavennaskonda, sest iga ümberlõigatu, kes on läbinud vajalikud initsiatsiooniperioodid, võib astuda teise, surnud bwami kohale. Ka võivad initsiatsiooni läbi teinud naised tõusta oma meestega võrdsele positsioonile.

Lega maskid on väga väljendusrikkad, kuigi nende vorm on lihtne ja klassikaline.

Sudaani päritolu zandesid jagub Kongo põhjaossa, Sudaani lõunaossa ja Kesk-Aafrika Vabariigi edelaaladele. Nende tähtsaimat skulptuuri nimetatakse yandaks ja selle ülesanne on kaitsta mani vennaskonna liikmeid, suurendades nende elujõudu ja kindlustades edu nende ettevõtmistele. Valmistatud puust või põletatud savist, kujutab yanda endast üldistatud, täispikkuses naisekuju. Otsevaates ja käteta, on sel naisekujul silmatorkavalt etteulatuv naba. 


\section{Roger Pierre Turine}

Sarnaselt oma naabritele zandedele on ka mangbetud Sudaani päritolu. Mangbetud elavad aristokraatliku klassi võimu all ja sellel aristokraatlikul klassil on oma realistlik rikkalikult kaunistatud tarbeesemetega oukonnakunst, mida iseloomustavad rohke dekooriga muusikariistad. Neil on ka pehmest puust, elevandiluust ja põletatud savist skulptuure.

Mangbetude eripäraks - nii argielus kui ka kunstis - on nende peakuju ja soengud. Varases lapsepõlves taimekiududega kängitsetud pea, mis omandas aastatega pikliku, tüüpilise "mangbetu kukla" vormid, peegeldub ka selle rahva kunstis: skulptuurides ja kuulsates, erineva kujuga põletatud savist vaasides, mille huvitavaid näiteid leiame Eesti Rahva Muuseumist.

Teine mangbetu tüüpiline kaunistatud tarbeese on negbwe ehk väike ovaalne taimekiududest naiste tuharakate.

Aafrika ulatas mulle oma käed tegelikult juba ammu enne minu esimesi kokkupuuteid tema suursuguse ja elujõudu täis kunstiga. See oli 1948. aastal, mil üks mu misjonärist onu siirdus Belgia Kongosse (praegune Kongo DV) ja mina, tookord kuueaastane poisike, lubasin teda lennukile saates, et lähen teda sinna vaatama. Kahjuks suri mu jesuiidist onu aasta tagasi, olles veetnud pool sajandit apostlite elureegleid järgides Kwilus ja Kinshasa regioonis.

Olen enda peale pahane, et ei jõudnudki talle külla, mina, kes ma tundusin talle loomu poolest piisavalt uudishimulik ja kelle vastu ta oli tundnud ka mõningat kiindumust, sest alles nüüd mõistan, kui särav oli tema sealviibimise aeg.

Kujutan ette oma rõõmu, kui saanuksin käia koos temaga nende mustanahaliste hulgas, keda ta armastas ja kelledest paljud on andnud oma järeltulijatele tema auks eesnime Turine.

Mulle oli antud oodata pool sajandit, enne kui astusin mandrile, mille võlu mind sestpeale magada ei lase. Inimeste lahkus, nende loomulik ilu ja eluterve seesmine vaist, nende naeratus, nende liigutuste pehmus, nende erakordne erksus, mida saadab muusika ja rütmi pidev kohalolek, ja nende kunst - nii eriline ja nii õige, sest õpetab elu elama, mitte tema üle juurdlema.

Tõlkinud Laura Talvet 
Roger Pierre Turine

\section{Kommentaarid}

${ }^{1}$ Vestlusest Ibrahim Diallo'ga.

${ }^{2}$ Sõna 'kultusese' on prantsuse keeles fétiche, millest ka sarnasus portugalikeelse sõnaga feitiço (tõlk).

\section{Kirjandus}

Bacquart, Jean-Baptiste 1998. L'art tribal d'Afrique noire. Paris: Assouline = Bacquart, Jean-Baptiste 1998. The tribal arts of Africa: Surveying Africa's artistic geography. London: Thames and Hudson.

Cornet, Joseph 1972. Art de l'Afrique noire au pays du fleuve Zaïre. Bruxelles: Arcade.

Gottschalk, Burkhard 1999. Lobi: Chez les devins du pays Lobi: L'art de decouvrir les choses cachees. Düsseldorf: Verlag U. Gottschalk.

Haumant, Jean-Camille 1998 [1929]. La tribu Lobi. Paris: Presses Universitaires [Touluse: Editions Toguna].

Kerchache, Jacques \& Stéphan, Lucien \& Paudrat, Jean-Louis 1998. L’Art Africain. L'art et les grandes civilisations 18. Paris: Ed. Mazenod \& Citadelles.

Leuzinger, Elsy 1962. Afrique: L'art des peuples noirs. Collection L'art dans le monde. Paris: Ed. Albin Michel = Leuzinger, Elsy 1961. Afrika: Kunst der Negervölker. Baden-Baden: Holle.

Phillips, Tom (toim) 1999. Africa: The Art of a continent. Munich \& London \& New York: Prestel.

Rubin, William (toim) 1991. Le Primitivisme dans l'art du XXe siècle: Les artistes modernes dans l'art tribal. Paris: Flammarion = Rubin, William (toim) 1984. "Primitivism" in 20th century art: Affinity of the tribal and the modern 1-2. New York: Museum of Modern Art.

Salmon, Pierre et al. (koost) 1976. L'Afrique Noire, Histoire et Culture. Bruxelles: Meddens.

Scanzi, Giovanni Franco 1993. L'art traditionnel Lobi $=$ Lobi traditional art. S. Paolo d'Argon (Bergamo): Ed. Milanos.

Stepan, Peter 2001. Africa. World Art. Munich \& London: Prestel Verlag = Stepan, Peter 2001. Afrika. Ikonen der Weltkunst. München [et al.]: Prestel

Vogel, Susan Mullin 1999. L'Art Baoulé du visible et de l'invisible. Paris: Ed. Adam Biro = Vogel, Susan Mullin 1997. Baule: African art, western eyes . 


\section{Roger Pierre Turine}

New Haven (Connecticut): Yale University Press \& Yale University Art Gallery.

Willett, Frank $1990=1994$. L'Art Africain. Collection Tout l'univers de l'art. Paris: Thames \& Hudson = Willett, Frank 1971. African art: An introduction. The World of art library, history of art. London: Thames \& Hudson = Willett, Frank 1971. African art: An introduction. Praeger world of art series. New York: Praeger = Willet, Frank 1993. African art: An introduction. World of art. New York: Thames and Hudson. 